\title{
Gender Variant
}

National Cancer Institute

\section{Source}

National Cancer Institute. Gender Variant. NCI Thesaurus. Code C160941.

An individual who does not conform to a male/female gender identity. 